\title{
Audit lessons from the economic Crisis: Rethinking audit quality
}

Citation for published version (APA):

Knechel, W. R. (2009). Audit lessons from the economic Crisis: Rethinking audit quality. Maastricht University. https://doi.org/10.26481/spe.20090911rk

Document status and date:

Published: 11/09/2009

DOI:

10.26481/spe.20090911rk

Document Version:

Publisher's PDF, also known as Version of record

\section{Please check the document version of this publication:}

- A submitted manuscript is the version of the article upon submission and before peer-review. There can be important differences between the submitted version and the official published version of record.

People interested in the research are advised to contact the author for the final version of the publication, or visit the DOI to the publisher's website.

- The final author version and the galley proof are versions of the publication after peer review.

- The final published version features the final layout of the paper including the volume, issue and page numbers.

Link to publication

\footnotetext{
General rights rights.

- You may freely distribute the URL identifying the publication in the public portal. please follow below link for the End User Agreement:

www.umlib.nl/taverne-license

Take down policy

If you believe that this document breaches copyright please contact us at:

repository@maastrichtuniversity.nl

providing details and we will investigate your claim.
}

Copyright and moral rights for the publications made accessible in the public portal are retained by the authors and/or other copyright owners and it is a condition of accessing publications that users recognise and abide by the legal requirements associated with these

- Users may download and print one copy of any publication from the public portal for the purpose of private study or research.

- You may not further distribute the material or use it for any profit-making activity or commercial gain

If the publication is distributed under the terms of Article $25 \mathrm{fa}$ of the Dutch Copyright Act, indicated by the "Taverne" license above, 


\section{Maastricht University}

Prof. dr. W. Robert Knechel

School of Business and Economics

Audit Lessons from the Economic Crisis:

Rethinking Audit Quality 
Audit Lessons from the Economic Crisis:

Rethinking Audit Quality 


\section{Colofon}

Design and print: Océ Business Services, Maastricht

ISBN: $978-90-5681-320-8$

NUR: 780

Alle rechten voorbehouden. Niets uit deze uitgave mag worden verveelvoudigd, opgeslagen in een geautomatiseerd gegevensbestand of openbaar gemaakt worden, zonder voorafgaande schriftelijke toestemming van de auteur of uitgever. 


\section{Audit Lessons from the Economic Crisis: Rethinking Audit Quality}

Inaugural Lecture

Delivered in English in an abridged form on accepting the position of Professor of Auditing at Maastricht University on Friday, 11 September 2009

Dr. W. Robert Knechel

Professor of Auditing 
Rector Magnificus, Colleagues, Ladies and Gentleman

\section{Introduction}

Audit quality is one of the most discussed topics among scholars who examine issues related to auditing and regulators who are charged with protecting the integrity of the financial reporting system. Because of the scandals and economic events during the past decade, the issue of financial reporting and audit quality is considered as important as ever. Before jumping into a discussion of audit quality, it is helpful to keep in mind that good audit quality means that an auditor is fulfilling his or her professional responsibilities. Consequently, any definition of audit quality is conditional on the accepted definition of those responsibilities. One description, which more or less mirrors the statements of many commentators, notes: "In what might be called the formative days of auditing, students were taught that the chief objects of the audit were: (1) detection and prevention of fraud and (2) detection and prevention of errors. In recent years there has been a decided change in demand and service. Present day purposes are: (1) to ascertain actual financial condition and earnings of an enterprise and (2) detection of fraud and errors ...". I think most auditing professional would agree with the spirit of this statement. What is interesting, however, is that it does not come from current professional standards or even a recent text book on auditing. Rather, the source of the statement is Montgomery's Auditing from 1912.

Obviously, the debate about audit quality and auditor responsibilities is not new, and it is unlikely to be settled any time soon. In this essay, I lay out eight propositions that, in my opinion, should be the foundation of future discussions about audit quality. While not intended to actually define audit quality, the propositions might hopefully serve as guidance to the formation of expectations as to what audit quality should be, and can become.

\section{Proposition 1: We still do not know how to define audit quality (let alone measure it).}

The classic definition of audit quality that is cited by most audit researchers is that of DeAngelo (1981): "the market-assessed joint probability that a given auditor will both (a) discover a breach in the client's accounting system and (b) report the breach." The definition highlights two aspects of audit quality that many would agree are important: (1) 
the competence of the auditor that determines how likely it is that a misstatement will be detected and (2) the independence/objectivity of the auditor that determines what the auditor is likely to do about a detected misstatement. This definition has been highly useful to audit researchers but, as I will argue below, it is much less useful to regulators and standard setters.

How does one know if an auditor has provided an adequate level of audit quality? Is quality in the "eye of the beholder" as a senior regulator was heard to say at a recent international conference? Recent discussions at the PCAOB highlight the problem of defining audit quality (PCAOB 2008). Is it an issue of the quality of inputs used in the audit process, the quality of the outputs, or both? If it is function of the quality of the inputs or outputs, how should they be measured? If both, how do the inputs relate to the outputs? Should quality be addressed at the engagement level or for the firm in its entirety? Is audit quality conditional on the characteristics of the client or a portfolio of clients? The Financial Reporting Council (FRC, 2008) of the UK issued a report identifying four main drivers of audit quality: (1) the culture within an audit firm; (2) the skills and personal qualities of audit partners and staff; (3) the effectiveness of the audit process; and (4) the reliability and usefulness of audit reporting. It only takes a quick glance to realize that all four of these drivers are vague and subject to interpretation, effectively replacing one opaque and hard-to-define term with four equally opaque and hard-to-define concepts. In the end, one begins to wonder if it is actually possible to ever know the quality of an audit.

\section{Proposition 2: Zero risk can not be the goal of audit quality.}

Part of the problem with the DeAngelo definition is that it is trying to define the unobservable. More importantly, the DeAngelo definition of audit quality suffers from another rather serious limitation-it contradicts auditing theory. As written, audit quality is unbounded in the DeAngelo definition, and more assurance is always considered better than less. This would lead to a predictable (but uninteresting and unrealistic) corner solution to any effort to "optimize" audit quality. Contrast this view with that impounded in the audit risk model which is the foundation of the audit process. The audit risk model assumes that an auditor has an assurance target in mind when conducting the audit, and while the level of assurance would be quite high, it is not complete or perfect. 
Perfect assurance is not possible for at least two reasons. First, society is unlikely to be willing to pay for the cost of work that would be necessary to even begin to approach perfect assurance. Second, perfect assurance is not an attainable goal when auditors must deal with issues related to the completeness of liabilities and the valuation of assets. The "completeness" objective in auditing requires that an auditor determine, for example, that there are no unrecorded liabilities. In essence this requires an auditor to search for things unknown, the accounting equivalent of "trying to prove a negative." In logic, the reasoning that you accept a statement as true just because you cannot prove it false is called argumentum ad ignorantiam. Somehow, I don't believe that the point of the audit is to "appeal to ignorance". Consequently, the inability of an auditor to verify the completeness of financial statements serves as an inherent limit on assurance.

The problem of verifying estimates is possibly even more difficult because this involves predicting the future. The only thing one can say with certainty about an auditor's or a client's respective estimates of bad debts is that they are both wrong. Auditors do not know the future, and tea leaves, crystal balls, tarot cards and Ouija boards are not part of the average auditor's tool box. In a sense, auditors are like weatherman, sometimes they get an answer that is close enough to being 'correct' that everyone is happy. However, if they get it too far wrong, it will rain on many a shareholder's "parade".

\section{Proposition 3: Audit quality as an outcome can not be completely separated from reporting quality.}

Many accounting and auditing scandals of the past decade have involved outright fraud by management, including recording fictitious inventory and hiding liabilities. However, just as often, the accounting problems in a company have had more to do with interpreting reporting standards in a highly aggressive manner. In the 1990s, most large telecoms were rapidly expanding their fiber optic networks around the world. Once telecoms had built their regional fiber optic networks, they needed to figure out how to link them to get global coverage. The solution for linking systems were "swap" transactions where two companies would sign a contract to allow the transmission of digital communications across each other's fiber optic networks. Swap transactions, much like airline alliances, facilitated global telecommunications. 
However, the industry practices for accounting for such transactions created opportunities for management to inflate earnings. More specifically, the accounting standards used for telecoms allowed the companies involved in swaps to record them as both a sale and purchase of inventory, resulting in a simultaneous increase in revenues and assets but without expending any cash or recognizing any expenses until future periods. These swaps were extremely useful to management if they wished to "puff up" revenues and earnings. However, it is also relatively easy to see that such swaps did not represent the completion of the earnings process that is the usual test for recognizing revenue. In most cases, recognition would require a subsequent transaction with an end user willing to pay for the actual use of the transmission time.

These transactions, given their effect on recorded revenue, were a significant contributor to the build up of the telecom bubble in the 1990s, as well as the subsequent crash, even though they were considered to be acceptable "industry practices" at the time. Global Crossing established the first fiber optic cable linking the US to Europe and used swap transactions to leverage its valuable asset. Enron set up a market to facilitate such swaps among a large group of telecoms, including Worldcom. Enron and Global Crossing went gloriously bankrupt in the same week, partially due to losses with their swap portfolios. Worldcom followed in the ensuing months. In a sense, these firms, along with a number of lesser known companies, were "done in" by a transaction where the accounting was "technically correct" but which served primarily to obfuscate the financial health of the organizations and the results of their operations. And lest we forget, telecom swaps were not the only example of debatable accounting practices at a time when accountants were being forced to cope with special purpose entities (Enron again), the acquisition of in-process R\&D, and barter transactions among internet companies recognized as advertising revenue (America OnLine)—all resulting in misleading financial reports in spite of being acceptable under accounting standards and signed off on by an auditor.

\section{Proposition 4: Any definition of audit quality should reflect that it is a professional service.}

To understand "audit quality" one must first understand "auditing". While it may seem like a trivial point, whether one considers auditing to be a noun ("an audit") or a verb ("to audit") has a significant effect on the lens that is used to view audit quality. The audit as a noun suggests 
that it is a black box that can be evaluated based on its output. What goes into the black box, or happens in the black box, is not relevant. However, audit quality is unobservable as an output, and the outcome of the audit may not correspond to the quality of the work performed. Auditing as a verb suggests something that a professional does on behalf of a client. Essentially, this is the nature of a "service". There are many types of services, for example, those provided by hotels, airlines and restaurants. These services are perishable and non-storable.

A more important feature of services is that the perception of their quality is usually based on how they are provided as much as their outcome. Virtually all airplane flights get the passengers to their destination (eventually), but there can be a great deal of variability in how the quality of a plane trip is perceived by the customers. Is the plane on time? Are the seats comfortable? Is the food edible? Does the luggage arrive? It does not matter how soft a hotel bed is if the bed linens are dirty; nor does it matter how many Michelin stars a restaurant has if the soup has a fly in it. In short, the process of providing a service matters a great deal.

Auditing is a service (Maleyeff, 2009). However, it should also be considered to be a professional service which is fundamentally different from hotels and airlines. For example, the audit report is non-perishable, at least for a foreseeable period of time, and the use of the audit report by one person does not preclude its use by another. As another example, the value of professional services is knowledge-based rather than assetbased: an audit's value derives from what the professional knows, i.e., their expertise. Exhibit 1 summarizes a number of dimensions which make auditing, or professional services in general, different from other services. Of particular importance is the recognition that an audit is a knowledge-based service where the primary in put is the time and expertise of individual professionals.

\section{Proposition 5: Audit quality is inherently uncertain and idiosyncratic.}

As noted earlier, the audit risk model does not assume perfect assurance. No auditor, client or regulatory inspector can ever really know what level of assurance is achieved in an audit. In most cases, the financial statements serve their purpose, no one questions their accuracy (too deeply), and the auditor is assumed to "have done his job". If nothing 
goes wrong with the client, no one is ever likely to look too hard at the quality of the audit. This does not mean that the auditor has provided the desired or planned level of assurance, however. If a scandal erupts at the client, or the client experiences a financial crisis, than many interested parties may take a hard look at the auditor's work. But again, they can never determine the actual level of assurance. With the benefit of hindsight, many may think the auditor did a bad job when a scandal erupts but it is important to realize that this insight is conditioned on the knowledge of the now-revealed scandal or financial distress. The auditor has to make their judgments without the advantage of hindsight and a good audit process can, nevertheless, result in a bad outcome. As an analogy, a criminal can go to jail due to the simple fact that he is guilty in spite of having a world class defense from his attorney. Did the attorney do a "bad" job because he lost the case? No matter what the attorney does, the final judgment is out of his hands. In a similar manner (without the criminal activity in most cases), an auditor can do a great job and still fail to discover a material misstatement, thus the concept of audit risk. Following this argument, and given that the level of assurance is unobservable, it then follows that a critical attribute of audit quality is its inherent uncertainty.

Additionally, judging audit quality is not the same as picking out the best toaster or pair of jeans from a display of similar items. Toasters may vary in color, functionality, price and warranty, but many customers can purchase the exact same model because they are manufactured in batches. In comparison, no two audits are identical. The characteristics of the each client are different. The risk profile of each client is different. The resources needed to conduct each audit are different. The personnel assigned to an audit vary from engagement to engagement. The attitudes, mood, attention and level of care vary for a given auditor from day-to-day. In the end, all of these differences conspire to make each audit idiosyncratic, meaning that every audit is essentially a one-off exercise. The fact that the quality of an audit is inherently uncertain and idiosyncratic means that audit quality is essentially a client-specific characteristic, and generalizations about a firm's audits may not be appropriate beyond specific engagements. 


\section{Proposition 6: Audit quality reflects how closely the achieved assurance level comes to the target (appropriate) assurance level.}

The audit process is designed to assess the likelihood of a material misstatement and reduce the likelihood of an undetected and uncorrected misstatement to an "appropriate" assurance level. In essence, the auditor's job is to diagnose the risk of a client and to treat that risk through the planning and conduct of specific audit procedures. The better the "diagnosis" the more likely that the "treatment" will achieve the desired goal, i.e., level of assurance. The nature of assurance is depicted in a probability distribution in Exhibit 2. Three possible definitions of assurance are relevant for our discussion: (1) target assurance, (2) planned assurance and (3) achieved assurance. The target assurance is the amount of comfort that the public demands. It implicitly reflects a balancing of the marginal costs and benefits of more assurance, and reflects that zero risk is not an option even though the public may be hesitant to admit this on an ex post basis. Planned assurance reflects the extent of risk that an auditor will tolerate at the end of the engagement. It should reflect the auditor's best guess as to what the market desires. Finally, achieved assurance reflects the extent of audit work actually performed in the engagement.

If audit quality depends on the auditor achieving the appropriate target level of assurance during the course of an engagement, then two types of audit failure may occur:

- Calibration Failure: Variance of planned assurance from target assurance. This is illustrated in Exhibit 2 by the region labeled (3).

- Execution Failure: Variance of achieved assurance from planned assurance. This is illustrated in Exhibit 2 by the region labeled (2).

Region (1) reflects the actual assurance achieved during the course of the audit. The DeAngelo definition would interpret the probability mass composed of (2) plus (3) plus (4) as a loss of audit quality. However, what should be obvious from Exhibit 2 is that the region labeled (4) is not a failure of audit quality. Rather, it reflects the residual risk that is appropriate given the circumstances of the audit. It is the error rate that the public is willing to tolerate given the marginal cost and benefits of the audit. Therefore, it follows that only the probability mass represented by (2) plus (3) represents the actual loss of audit quality for a specific engagement. 
A calibration failure suggests that the auditor has not established the appropriate level of assurance as the target of the engagement. As a result of a calibration error, even if the auditor conducts a "perfect" audit, he will not achieve society's objectives for the client. In most cases, this means that the auditor will have a target level of assurance that is too low (equivalent to a risk level that is too high). This is not to say that society can demand zero risk though. As noted in Proposition 2, zero risk can not be the goal of an audit and society must implicitly weigh the marginal cost of extra assurance against its marginal benefit when assessing the appropriate level of assurance.

An interesting possibility is that the auditor sets the planned assurance too low but the achieved assurance actually exceeds what is planned, a possibility that may be due to extra work because the auditor wishes to be cautious or conservative. While the extra work would reduce the effect of the calibration error, it may not be enough to achieve the appropriate level of assurance. In such a situation, the auditor may look as if he or she is highly effective while simultaneously failing to live up to society's expectations. If the auditor ignores the calibration error, he or she may feel that the public is being unrealistic rather than looking at their own error in setting planned assurance. The frequently-cited "expectations gap" in auditing may simply be a manifestation of a systematic gap between the auditor's planned assurance and the public's desired, but less than perfect, level of assurance.

It is also possible for an auditor to set the target assurance at too high a level, whether due to a misunderstanding of the demands of the stakeholders or an incentive to bill for extra work that may not really be necessary. While the latter possibility may seem farfetched, one only needs to look at the debate surrounding the implementation of Section 404 of the Sarbanes-Oxley Act of 2002 to see how stakeholders (and regulators) could be put into a position where they believed they were being "over-audited".

The theory of credence goods in the economic literature (Dulleck and Kerschbamer, 2006) supports the possibility that an auditor will actually over-audit a client. A credence good is one where the purchaser can not know their own need or observe the quality of what they purchase even after consumption. Medical care and car repairs are often cited as examples of credence goods (services). One possible outcome 
of the information asymmetry between buyers and sellers is that the seller may deliver-and charge for-more of a service than the customer actually needs, i.e., replacing expensive car parts when all that is needed is a new oil filter. Since the average car owner can not judge the appropriateness of the repairs, the car mechanic's actions may never be detected. In a similar sense, the audit, whose quality is unobservable in most cases, may be a type of credence good for which an auditor has an incentive to "overwork" (Causholli and Knechel 2009). Since audits are often billed by the hour, there is a built in incentive to maximize the use of staff auditors on many engagements since each hour billed includes a profit margin. Such behavior may actually increase audit quality, assuming the staff are doing something useful, but the excess effort may not be pareto efficient for the client or the market as a whole (Knechel, Suijs and Willekens 2008).

\section{Proposition 7: The primary causes of an execution failure are misdiagnosis and inappropriate treatment of risk.}

In general, execution failure would arise if (1) the auditor does not accurately "diagnose" the risk of the audit or (2) the audit program used to guide audit testing does not effectively "treat" the risk. Risk assessment is a critical aspect of every audit. The auditor usually reviews a client's business and operations, internal control system, and preliminary analytical evidence to assess which accounts or transactions are most likely to be misstated. The judgments about risk are captured in the auditor's assessment of the risk of material misstatement for significant classes of transactions or accounts. If an auditor overlooks a risk, misjudges the significance of a risk, or fails to plan adequate tests to compensate for a risk, the resulting audit work will be ineffective and/or inadequate. Even in the case where the auditor accurately assesses the riskiness of a client, errors can still occur. An auditor may use weak audit procedures, assign tests to personnel without adequate expertise or experience to carry them out, misinterpret audit evidence, or fail to properly act on indications of accounting problems signaled by the evidence. These problems are often described as sampling and nonsampling error. Further, they match the conditions of audit quality incorporated into the DeAngelo definition. However, it is also interesting to note that this is where most discussions of audit quality start, thus overlooking a number of critical aspects of audit quality previously mentioned. 


\section{Proposition 8: The quality of auditing is inherent in the nature and execution of the activities that diagnose and treat risk in the audit process.}

The final proposition integrates the essence of all the other propositions. Given that the audit is a professional service with uncertain outcomes, executed by individuals in response to idiosyncratic client conditions, the ex post revealed state, when known, can not define the quality of the audit. Rather, the quality of the audit is inherent in the process used to conduct the audit. In essence, the quality of the audit process determines the quality of the audit. This means that audit quality is infused in an auditor's ability to appropriately internalize the reasonable expectations of the market and diagnose and treat risky conditions within a client.

What are the implications of this perspective on audit quality? First, since most audit research looks at outcome proxies to judge audit quality (accruals, going concern opinions), it is not clear whether researchers are actually capturing measures of audit quality. Consistent with the DeAngelo definition, the outcome proxies used by most researchers are designed to measure the probability mass (2) plus (3) plus (4) in Exhibit 2. I have already argued that this approach can understate audit quality since (4) does not represent a failure of the audit. This distinction may or may not matter in the interpretation of existing research. If the majority of audits are consistent with the pattern depicted in Exhibit 2 (i.e., achieved assurance < planned assurance < target assurance), then the understatement of audit quality may be a scaling difference and the proxies can be appropriately interpreted as measures of relative quality.

However, if there are a significant number of audits that exceed target assurance, then the interpretation of the proxies could be misleading. This follows from the fact that overauditing in one engagement can not compensate for underauditing in another. Further, to the extent an achieved assurance in excess of target actually reflects overauditing, such behavior may not be pareto efficient across society as a whole. In these cases, audit effort should probably be reduced. This interpretation is in direct contrast to the DeAngelo approach which would suggest further increases in effort to drive the residual risk even lower. Finally, the subsamples of over- and under-auditing reflect different problems, and pooling them into a single sample obscures their individual significance and may lead to misleading results in an empirical analysis. 
There are also important implications for audit practice. Again, if process quality is essentially audit quality, then professional efforts to regulate and improve the audit process can be considered to be helpful for improving audit quality. Thus, educational requirements, staff training, auditing standards, and peer review or inspections that focus on the audit process can all be beneficial. However, it is also important to keep in mind our fifth proposition, namely, that audits are idiosyncratic. This suggests that the same audit process is not necessarily effective or appropriate for all clients. In auditing, "one size does NOT fit all". Consequently, if education, training, standards and inspection are primarily aimed at increasing the standardization of the audit, they may not lead to an improvement in audit quality.

Ultimately, judgment and flexibility may be more important for achieving high quality audits. However, utilizing judgment and flexibility also opens individual auditors to second-guessing and potential sanctions, especially when things go wrong. An auditor who does the right things, but not necessarily the standard procedures, to minimize the loss of audit quality associated with regions (2) and (3), may be more susceptible to hindsight and second-guessing when an audit happens to fall into region (4) by "bad luck". Then, a lack of standardization and the reliance on judgment and flexibility may increase the professional opprobrium and sanctions imposed on the auditor for "making a mistake". At the same time, excessive standardization may not do much to reduce regions (2) and (3) because it ignores the idiosyncratic nature of the audit (e.g., see Asare and Wright 2004). This may not be visible in the vast majority of cases because very few audits will exhibit any observable signs of failure. In the end, this pattern creates what may be the supreme irony of audit quality: the quality of audit processes determines the quality of the audit but systematic efforts to make audit processes more standardized may have the effect of reducing the quality of audit outcomes.

To close, I hope the eight propositions presented in this essay lead readers to think about audit quality in different ways. Audit quality is a complex concept, made more complicated by the fact that it can not be clearly defined, accurately measured or routinely observed. Since auditing is a form of professional service, one general observation can be made: audit quality is imbued in process quality. That is, while the outcome of the audit can not be observed, the way in which an audit is conducted can be. Efforts to improve processes in the audit will gene- 
rally lead to better audit quality. However, standardization, inspection and hindsight may not always lead to improvements in audit quality if auditor judgment and flexibility is considered a limitation of the audit process, rather than an asset. In the end, the best source of audit quality may be the judgment and expertise of an experienced auditor in dealing with an uncertain and idiosyncratic environment of each individual client. 


\section{Acknowledgements}

Rector Magnificus, colleagues and ladies and gentleman, I am now at the end of this lecture and would like to take a moment to address a word of thanks to a number of individuals, present and absent, who have contributed to my career that is now approaching 30 years. This appointment is the culmination of a large number of assistances, collaborations and interactions along the way. While the path has not always been smooth, I have been extremely fortunate to have met a large number of interesting, engaging, tolerant and enthusiastic individuals at every corner and bend along the way.

First, I would like to acknowledge the support of the other full professors in accounting here in Maastricht, without whom this appointment would not be possible: Frank Moers, Roger Meuwissen, Eddy Vaassen, Harold Hassink and Steven Maijoor.

Much of my thinking on auditing and audit theory has been informed over the years through fascinating and ongoing discussions with a number of thought leaders in the auditing academy including: Tim Bell, Bill Messier, Mike Bamber, Mike Willenborg, Brian Ballou, Steve Salterio, Ted Mock, Ed O’Donnell, Stuart Turley, Morley Lemon, Ira Solomon, Mark Peecher, and Philip Wallage.

My research productivity has been facilitated by the extensive and valuable contributions of a large number of collaborators on three continents. Here in Maastricht, I would like to acknowledge my successful collaborations with Ann Vanstraelen, Caren Schelleman, and Rogier Deumes. In the Netherlands in general, I have had very productive relationships with Anna Gold, Liesbeth Bruynseels, Jeroen Suijs, and Niels van Niuew Amerongen. Around Europe, I have benefited from joint efforts with Marleen Willekens, Ann Gaeremynck, Lasse Niemi, and Aasmund Eilifsen. On a broader international scale I sincerely thank David Hay, Paul Rouse, and Vic Naikur in New Zealand, as well as Kevan Jensen, Jeff Payne, Jeff Casterella, Divesh Sharma, Monika Causholli, and David Sappington in North American, for their willingness to work with me on various intriguing projects.

Finally, all this is only possible with the support of my family. My parents passed away in recent years but they were always fascinated by, and proud of, my accomplishments, especially at the international level. 
They took great pleasure in regaling their friends with my travel schedule, probably to the chagrin of those friends. My wife Anna, and children Abigail, Martina and Andrew, while suffering through my many absences, have always been completely and enthusiastically behind me in my efforts. Without their love and support I would not be here today.

ik heb gezegd. 


\section{References}

AICPA

Asare, S. K., \& Wright, A. M. (2004). The effectiveness of alternative risk assessment and program planning tools in a fraud setting. Contemporary Accounting Review, $21(2), 325-352$.

Causholli, M. and W.R. Knechel (2009). Is the Audit a Credence Service? Working Paper, University of Florida.

DeAngelo, L. (1981). Auditor size and audit quality. Journal of Accounting and Economics 3 (December): 183-199.

Dulleck, U. and R. Kerschbamer (2006). On Doctors, mechanics, and computer specialists: The economics of credence goods. Journal of Economic Literature 44 (March): 5-42.

Financial Reporting Council (2008). The Audit Quality Framework. Available at: http://www.frc.org.uk/documents/pagemanager/frc/promoting_audit_quality responses/audit\%20quality\%20framework\%20for\%20web.pdf

Knechel, W.R., J. Suijs and M. Willekens (2008). A stakeholder model of competing demands for control and auditing. Working Paper, University of Florida/University of Tilburg.

Maleyeff, J. (2009). Analysis of service process characteristics across a range of enterprises. Journal of Service Science and Management (March): 29-35.

Montgomery, R.H. (1912). Montgomery's Auditing.

PCAOB Standing Advisory Group (2008). Discussion - Treasury Advisory Committee's Recommendation relating to the Feasibility of Developing Key Indicators of Audit Quality and Effectiveness. Available at: http://www.pcaobus.org/standards/standing_advisory_group/meetings/2008/ 10-22/bp_feasability_aqi.pdf 


\section{Exhibit 1}

Attributes of a Professional Service

\begin{tabular}{|c|c|c|c|}
\hline Attribute & Manufacturing & Services & Professional Services? \\
\hline Output & Product & Asset-based service & $\begin{array}{l}\text { Knowledge-based } \\
\text { service }\end{array}$ \\
\hline Outcome & Tangible product & Specific result & Uncertain result \\
\hline Nature of service & Incidental & $\begin{array}{l}\text { Standardized } \\
\text { Perishable }\end{array}$ & $\begin{array}{l}\text { Idiosyncratic } \\
\text { Non-perishable }\end{array}$ \\
\hline Resources & Capital and labor & Labor and capital & Labor \\
\hline Pricing & $\begin{array}{l}\text { Product demand } \\
\text { based }\end{array}$ & $\begin{array}{l}\text { Service demand } \\
\text { based }\end{array}$ & Time based \\
\hline Productivity & Resource mix & Resource mix & Labor mix \\
\hline $\begin{array}{l}\text { Performance } \\
\text { evaluation }\end{array}$ & $\begin{array}{l}\text { Customer satisfaction } \\
\text { I/O balance }\end{array}$ & $\begin{array}{l}\text { Customer satisfaction } \\
\text { Capacity balance }\end{array}$ & $\begin{array}{l}\text { Stakeholder satisfaction } \\
\text { Capability balance }\end{array}$ \\
\hline
\end{tabular}

\section{Exhibit 2}

Audit Quality in Terms of Assurance Levels

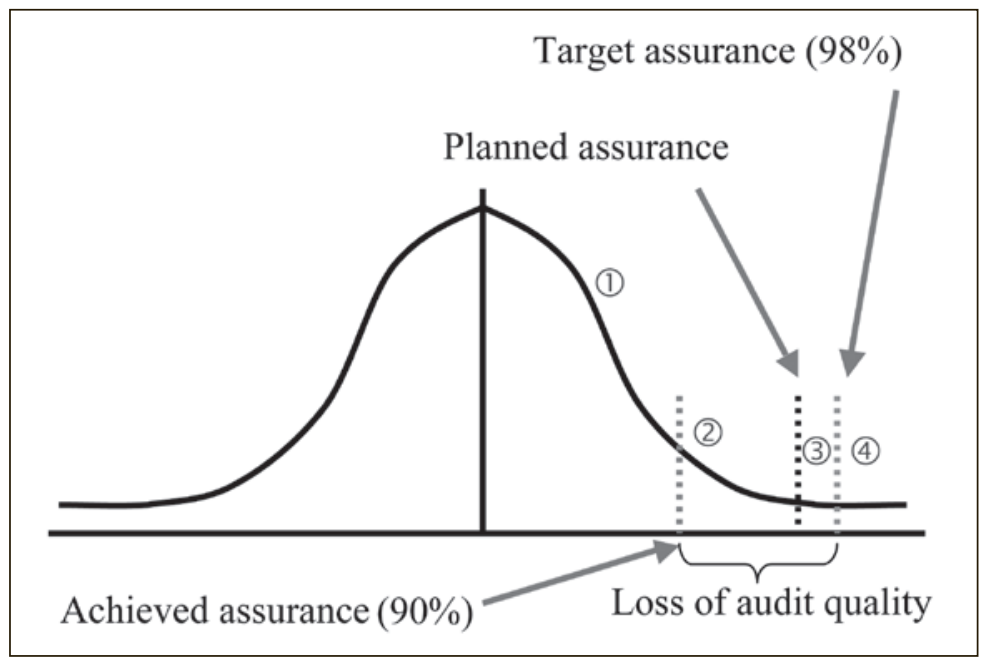


